\title{
DEVELOPMENT OF A POSITRON EMISSION TOMOGRAPHY RADIOPHARMACEUTICAL FOR IMAGING THYMIDINE KINASE GENE EXPRESSION: SYNTHESIS AND IN VITRO EVALUATION OF 9-\{(3-[ $\left[{ }^{18}\right.$ F]FLUORO-I-HYDROXY-2-PROPOXY)METHYL $\}$ GUANINE
}

\author{
Michel Monclus, $\uparrow$ André Luxen, $\S$ Vincent Cool, $\$$ Philippe Damhaut, $\uparrow$ Thierry Velut $\$$, Serge Goldman $\dagger$
}

$\uparrow$ PET/Biomedical Cyclotron Unit

\$ Department of Medical Genetics, ULB-Hôpital Erasme, 808 route de Lennik, 1070 Bruxelles - Belgium

$\S$ Centre de Recherches du Cyclotron, Université de Liège, B30, 4000 Liège - Belgium.

\begin{abstract}
:
9-[(3-fluoro-l-hydroxy-2-propoxy)methyl]guanine (FHPG) 2 has been labeled with fluorine-18 and evaluated in vitro as a potential radiotracer for mapping gene expression in vivo with positron emission tomography (PET). Recently new approaches of gene therapy have been proposed for the treatment of various human diseases. Among them, a promising gene therapy protocol for cancer consists of the transduction of neoplastic cells with the herpes simplex virus thymidine kinase gene (HSV-tk) which renders transduced cells sensitive to the lethal effect of antiviral agent such as ganciclovir (DHPG) 1. [1]

Positron emission tomography (PET) with adapted radiotracers represents a potential tool to determine the in vivo level of HSV-tk expression and to establish the optimal protocol of gene and ganciclovir administration in human. Until now, only a few molecules with potential applications to PET have appeared in the literature. 5Iodo-2'-fluoro-2'-deoxy-1- $\beta$-D-arabinofuranosyl-5-iodouracil (FIAU) [2,3] and 8-fluoro-9-[(2-

hydroxyethoxy)methyl]guanine [4] have been investigated as possible candidates for PET studies. Synthesis of 9-[(3-[ $\left.{ }^{18} \mathrm{~F}\right]$ fluoro-1-hydroxy-2-propoxy)methyl]guanine 2 was recently achieved $[5,6]$ and we report here our preliminary results with this molecule. Acyclic guanosine analogs are known to be potent antiviral agents against the herpes virus. Martin et al. first described FHPG and showed that it was less active than ganciclovir against herpes simplex virus 1 (HSV-1) in in vitro assays but none the less remained a good substrate for viral thymidine kinase. [7]
\end{abstract}<smiles>Nc1nc2c(ncn2COC(CO)CO)c(=O)[nH]1</smiles>

1

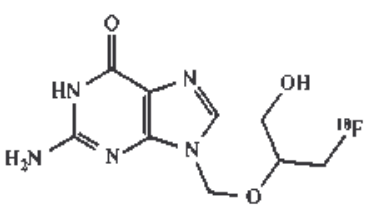

2

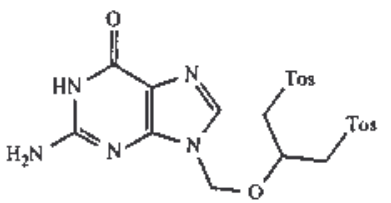

3

Radiosynthesis of $\mathbf{2}$ was achieved by nucleophilic $\left[{ }^{18} \mathrm{~F}\right]$ fluorination of the ditosylate 3 [8] followed by a basic hydrolysis and HPLC purification with a 3\% (decay corrected) radiochemical yield.

In a typical experiment, anhydrous potassium $\left[{ }^{18} \mathrm{~F}\right]$ fluoride/K222 [9] was added to a suspension of 3 in acetonitrile. The solution was refluxed for 30 minutes. The acetonitrile mixture was diluted with water $(20 \mathrm{~mL})$ and the whole solution was passed through an activated C18 Sep Pak ${ }^{\circledR}$ column (Waters). The column was washed with $10 \mathrm{~mL}$ of $1 \mathrm{M} \mathrm{HCl}, 10 \mathrm{~mL}$ of water and the activity was eluted with $2 \mathrm{~mL}$ of ethanol. The solvent was concentrated and $1 \mathrm{~mL}$ of $1 \mathrm{M} \mathrm{KOH}$ was added. The solution was refluxed for 30 minutes, cooled and acidified with $1 \mathrm{M} \mathrm{HCl}$ until $\mathrm{pH}$ 1.5. The resulting solution was injected on a semi-preparative HPLC column $\left(\mathrm{C} 8,10 \mu \mathrm{m}, 10\right.$ X $250 \mathrm{~mm}$; eluent $50 \mathrm{mM} \mathrm{NH} \mathrm{mAC}_{4} \% \mathrm{CH}_{3} \mathrm{CN}$; flow rate $7 \mathrm{~mL} / \mathrm{min}$, UV detection: $\lambda=254$ $\mathrm{nm})$. The appropriated radioactive fraction was collected at about 12 minutes, acetonitrile was removed under reduced pressure and the isotonicity of the solution was adjusted with sodium chloride. The purified radioactive compound was analyzed by HPLC $\left(\mathrm{C} 18,5 \mu \mathrm{m}, 4.6\right.$ X $250 \mathrm{~mm}$; eluent $50 \mathrm{mM} \mathrm{NH} \mathrm{OAC}_{4} \% \mathrm{CH}_{3} \mathrm{CN}$; flow rate 1 $\mathrm{mL} / \mathrm{min}$, UV detection: $\lambda=254 \mathrm{~nm}$ ) and was coeluted with an authentic sample which was synthesized using the procedure described by Martin et al. For in vivo experiments the solution may be sterilized by passing through a $0.22 \mu \mathrm{rn}$ filter membrane (Cathivex ${ }^{\circledR}$,Waters) before isotonicity adjustment with sterile sodium chloride.

The cytotoxic effect of FHPG, DHPG and acyclovir on cell growth was evaluated on cells maintained in culture. The cell lines used have been described elsewhere. In short, the 9L cell line is a chemically induced gliosarcoma from the Fischer 344 rat strain. The 9Ltk + cells were obtained by transfer of the herpes simplex type 1 thymidine 
kinase and the neomycine resistance gene. The 9Ltk- cells were obtained by transfer of the neomycine resistance gene. This procedure was described by Cool et al, [10] where 9Ltk+ refers to 9L transduction with the pTCM1LTKSN vector and 9Ltk- refers to 9L transduction with the pLXSN vector.

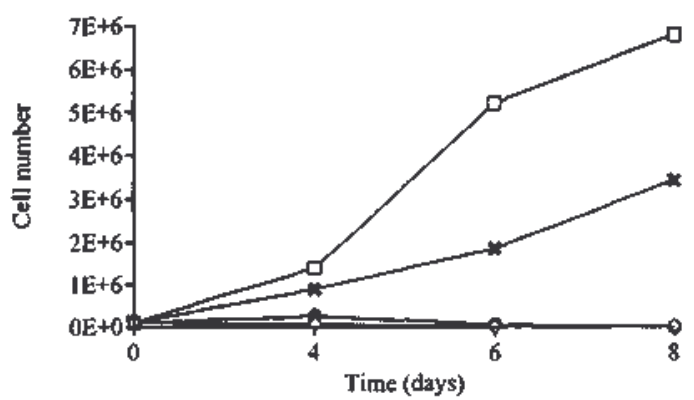

Figure 1. Effect of FHPG, DHPG and ayclovir on cell growth. Cells (9Ltk+) were incubated with no drug as control (口), with FHPG at $100 \mu M(X)$, with DHPG at $10 \mu M(\bullet)$ or with acyclovir at $100 \mu M(0)$ for 4, 6 and 8 days.

In 9Ltk + cells, the cytotoxic effects of FHPG was evaluated and compared to those of two well established antiviral drugs: acyclovir and DHPG. FHPG at $100 \mu \mathrm{M}$ inhibits the cell growth by 50\% while DHPG at $10 \mu \mathrm{M}$ and acyclovir at $100 \mu \mathrm{M}$ completely stopped the process (Fig. 1). These data were in good agreement with those described by Martin et al. [7] It is noteworthy that we were using for this test the racemic mixture of FHPG and that pure enantiomers might have different antiviral activities. [11-14]

Phosphorylated forms of $\left[{ }^{18} \mathrm{~F}\right] \mathrm{FHPG}$ should theoretically accumulate in cells expressing HSV-tk. We have tested the in vitro uptake of no-carrier-added (n.c.a.) $\left[{ }^{18} \mathrm{~F}\right] \mathrm{FHPG}$ in $9 \mathrm{Ltk}+$ and $9 \mathrm{Ltk}$ - cells. On day $0,2.510^{6}$ 9Ltk + or 9Ltk- cells were seeded in Petri dishes in duplicate for each experimental group and timing. On day 2 ,

$\left[{ }^{18} \mathrm{~F}\right] \mathrm{FHPG}(7.4 \mathrm{MBq})$ was added in each dish. After 30, 60, 120, 240 and 360 minutes of incubation at $37^{\circ} \mathrm{C}$ under a $\mathrm{CO}_{2}$ and water controlled atmosphere, culture medium was discarded and cells were washed 3 times with $5 \mathrm{~mL}$ of culture medium and harvested after trypsinization. All samples were counted in a $\gamma$ spectrometer. Accumulation of $\left[{ }^{18} \mathrm{~F}\right] \mathrm{FHPG}$ in 9Ltk + and 9Ltk- cells is shown in Figure 2. In two different experiments, the radioactivity ratio in 9Ltk+ and 9Ltk- cells (corrected for the number of cells) was respectively 234 and 243 after 360 minutes of incubation.

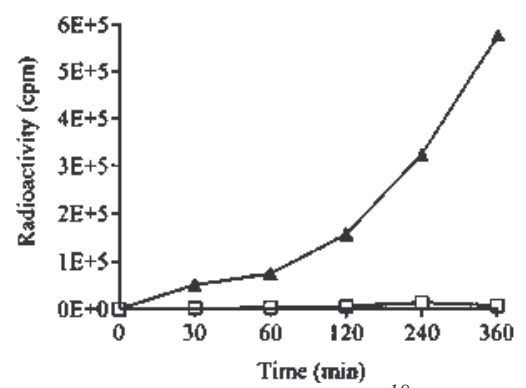

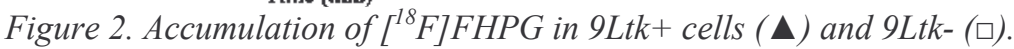

The above cell pellets were treated with $300 \mu \mathrm{L}$ of $1 \%$ sodium dodecyl sulfate and $80 \mu \mathrm{L}$ of $3 \%$ perchloric acid. After centrifugation, $250 \mu \mathrm{L}$ of the supernatant were then added to $250 \mu \mathrm{L}$ of HPLC solution $\left(\mathrm{KH}_{2} \mathrm{PO}_{4} 0.01 \mathrm{M}\right.$; $\mathrm{pH} 3.5)$. The extracts $(100 \mu \mathrm{L})$ were analyzed by HPLC with a Whatman Partisil SAX column $(10 \mu \mathrm{rn}, 4.6 \mathrm{X}$ $250 \mathrm{~mm}$, UV detection: $\lambda=254 \mathrm{~nm})$. [15] The column was eluted at a flow rate of $1 \mathrm{~mL} / \mathrm{min}$ with a linear gradient of $\mathrm{KH}_{2} \mathrm{PO}_{4}, 0.01$ to $1 \mathrm{M}(\mathrm{pH} 3.5)$. A 30 minutes gradient was followed by 15 minutes at $1 \mathrm{M}$ buffer to elute the triphosphate. Fractions of $2 \mathrm{~mL}$ were collected and assayed for radioactivity by $\gamma$ spectrometry. HPLC retention times of $\left[{ }^{18} \mathrm{~F}\right] \mathrm{FHPG}$ and $\left[{ }^{18} \mathrm{~F}\right] \mathrm{FHPG}$ monophosphate were 6 and 10 minutes respectively.[16] 


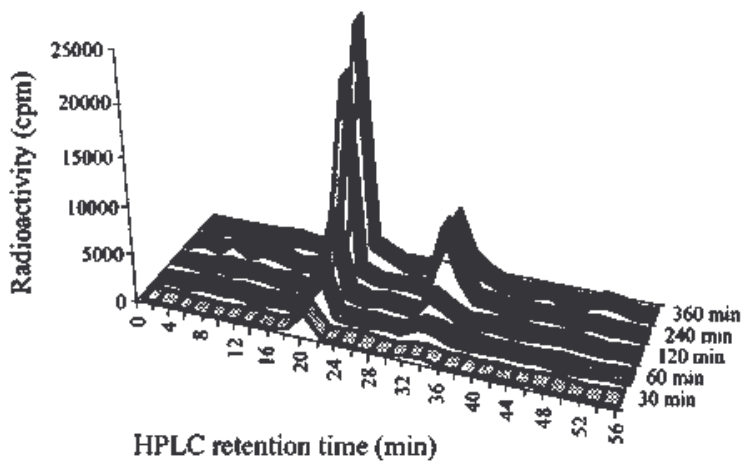

Figure 3. HPLC analysis of the metabolites of $\left[^{18} \mathrm{~F}\right] \mathrm{FHPG}$ in 9Ltk+ cells after 30, 60, 120, 240 and 360 min of incubation.

Analysis of $\left[{ }^{18} \mathrm{~F}\right] \mathrm{FHPG}$ metabolites in 9Ltk + cells is shown in Figure 3.

The results of these experiments clearly show that, despite a relatively weak cytotoxic effects on 9Ltk + cells in comparison to acyclovir and DHPG, $\left[{ }^{18} \mathrm{~F}\right] \mathrm{FHPG}$ was strongly incorporated (7.6\% of total activity; decay corrected) into 9Ltk+ cells. This confirms the previous results described by Martin et al. [7] The HPLC analysis provides some explanation on the reduced pharmacological activity of FHPG.

As a matter of fact, Figure 3 shows that the relative amount of the different chemical species remains approximately the same from 30 to 360 minutes after exposure to $\left[{ }^{18} \mathrm{~F}\right] \mathrm{FHPG}$, with a clear prevalence of two more polar metabolites beside $\left[{ }^{18} \mathrm{~F}\right] \mathrm{FHPG}$ monophosphate. These observations are in good agreement with those previously reported. [17]

In the same conditions, retention time of $\left[{ }^{3} \mathrm{H}\right] \mathrm{DHPG}$ mono-, di- and triphosphate peaks are 11, 19 and $32 \mathrm{~min}$, respectively; $\left[{ }^{3} \mathrm{H}\right]$ acyclovir mono-, di- and triphosphate peaks eluted at 11, 21 and 35 minutes, respectively. If, as suspected, the more polar metabolite is the $\left[{ }^{18} \mathrm{~F}\right] \mathrm{FHPG}$ triphosphate, and since this form should be the active one for DNA polymerase inhibition, we may postulate that the minor production of $\left[{ }^{18} \mathrm{~F}\right] \mathrm{FHPG}$ triphosphate $(25 \%)$ in our system explains that we found weak anti-proliferation activity of FHPG.

These observations prompt us to conclude that $\left[{ }^{18} \mathrm{~F}\right] \mathrm{FHPG}$ is a promising PET tracer for the evaluation of gene therapy involving thymidine the kinase gene.

Acknowledgment: The authors wish to thank Syntex for providing ganciclovir. This work was supported by grants from CGER, FNRS (3.4533.94 - 3.4539.96) and Loterie Nationale (9.4516.95).

\section{References and Notes}

[1] Culver, K. W.; Ram, Z.; Wallbridge, S.; Ishii, H.; Oldfield, E. H.; Blaese, R. M. Science 1992,256, 1550.

[2] Tjuvajev, J. G.; Stockhammer, G.; Desai, R.; Uehara, H.; Watanabe, K.; Gansbacher, B.; Blasberg, R. G. Cancer Res. $1995,55,6126$.

[3] Tjuvajev, J. G.; Finn R.; Watanabe, K.; Joshi, R.; Oku, T.; Kennedy, J.; Beattie, B.; Koutcher, J.; Larson, S.; Blasberg, R. Cancer Res. $1996,56,4087$.

[4] Barrio, J. R.; Namavari, M.; Phelps, M. E.; Satyamurthy, N. J. Org. Chern. 1996, 61, 6084.

[5] Monclus, M; Luxen, A.; Van Naemen, J.; Damhaut, P.; Velu, T.; Cool, V.; Goldman, S. J Labelled CompdRadiopharm 1995, $37,193$.

[6] Alauddin, M. M; Conti, P. S.; Mazza, S. M.; Hamzeh, F. M.; Lever, J. R. Nuclear Medecine \& Biology $1996,23,787$.

[7] Martin, J. C; McGee, D. P. C; Jeffry. G. A.; Hobbs, D. W.; Smee, D. F.; Matthews, T. R.; Verheyden, J. P. H. J. Med. Chem. 1986, 29, 1384.

[8] Preparation of 9-\{[1,3-di(p-toluenesulfonyloxy)-2-propoxy]methyl $\}$ guanine 3 . To a suspension of DHPG 1 (255 mg, $1 \mathrm{mmole})$ in anhydrous pyridine $(2 \mathrm{~mL})$ was added with a syringe $p$-toluenesulfonyl chloride $(955 \mathrm{mg}, 5 \mathrm{mmoles})$ previously dissolved in anhydrous pyridine $(1 \mathrm{~mL})$. After addition, the suspension was allowed to stand at room temperature for $12 \mathrm{~h}$. The solution was then poured in $1 \mathrm{M}$ $\mathrm{HCl} /$ ice and then filtered. The crude material was purified by using column chromatography $\left(\mathrm{SiO}_{2}, \mathrm{CH}_{2} \mathrm{Cl}_{2} / \mathrm{methanol}\right.$ 9/1 and then $\mathrm{CH}_{2} \mathrm{Cl}_{2}$ /methanol: 8/2) to afford pure ditosylate $3(230 \mathrm{mg}, 40 \%)$ as a solid mp 272-273 ${ }^{\circ} \mathrm{C}(\mathrm{dec}) .{ }^{1} \mathrm{H}-\mathrm{NMR}(250 \mathrm{MHz}, \mathrm{DMSO}-d 6): \delta 2.41$ (s, $\left.6 \mathrm{H}, \mathrm{CH}_{3}\right), 3.88\left(\mathrm{dd}, \mathrm{J}=5.7,10.6 \mathrm{~Hz}, 2 \mathrm{H}, \mathrm{CH}_{2}\left(5^{\prime}\right)\right), 4.02\left(\mathrm{dd}, \mathrm{J}=3.5,10.7 \mathrm{~Hz}, 2 \mathrm{H}, \mathrm{CH} 2\left(3^{\prime}\right)\right), 4.08-4.12\left(\mathrm{~m}, 1 \mathrm{H}, \mathrm{CH}\left(4^{\prime}\right)\right), 5.28(\mathrm{~s}, 2 \mathrm{H}, \mathrm{CH})$, $6.57(\mathrm{~s}, 1 \mathrm{H}, \mathrm{NH}), 7.43(\mathrm{~d}, \mathrm{~J}=8.25 \mathrm{~Hz}, 2 \mathrm{H}), 7.65(\mathrm{~d}, \mathrm{~J}=7.8 \mathrm{~Hz}, 2 \mathrm{H})$; HPLC-MS $[\mathrm{M}+\mathrm{H}]^{+}: 564$.

[9] Guillaume, M.; Luxen, A.; Nebeling, B.; Argentini, M.; Clark, J. C; Pike, V. W. Appl. Radial, Isot. 1991, 42, 749.

[10] Cool, V.; Pirotte, B.; Gerard, C; Dargent, J.-L.; Baudson, N.; Levivier, M.; Goldman, S.; Hildebrand, J.; Brotchi, J.; Velu, T. Hum. Gen. Ther. 1996, 7, 627

[11] Ashton, W. T.; Canning, L. F.; Reynolds, G. F.; Tolman, R. L.; Karkas, J. D.; Liou, R.; Davies, M.-E. M.; DeWitt, C. M.; Perry, H. C; Field, A. K. J. Med. Chem. 1985, 28, 926.

[12] Karkas, J. D.; Germershausen, J.; Tolman, R. L.; MacCoss, M.; Wagner, A. F.; Liou, R.; Bostedor, R. Biochim. Biophys. Acta 1987, $911,127$.

[13] Kohlbrenner, W. E.; Carter, C. D.; Fesik, S. W.; Norbeck, D. W.; Erickson, J. Biochem. Pharmacol. 1990, 40, R5.

[14] Synthesis of R and S enantiomers of FHPG. M. Monclus. Unpublished data.

[15] Elion, G. B.; Furman, P. A.; Fyfe, J. A.; de Miranda, P.; Beauchamp, L.; Schaeffer, H. Proc. Natl. Acad. Sci. USA 1977, 74,5716.

[16] An authentic sample of FHPG monophosphate was prepared by treating N-acetyl-FHPG with 2-cyanoethyl N,N-

diisopropylchlorophosphoramidite. Conversion to the intermediate dicyanoethyl-phosphoramidite and subsequent oxidation, deprotection and purification by HPLC on a SAX column afforded the desired compound.

[17] Smee, D. F.; Boehme, R.; Chernow, M.; Binko, B. P.; Matthews, T. R. Biochem. Pharmacol. 1985, $34,1049$. 